\title{
Distribution of Different Organotin and Organolead Compounds in Sediment of Suez Gulf
}

\author{
Mohamed A. Shreadah ${ }^{1}$, Tarek O. Said ${ }^{1 *}$, Safaa A. Abd El Ghani ${ }^{1}$, Abd El Moniem M. Ahmed ${ }^{2}$ \\ ${ }^{1}$ National Institute of Oceanography and Fisheries, Kayet Bay, Alexandria, Egypt; ${ }^{2}$ Chemistry Department, Faculty of Science, \\ Alexandria University, Alexandria, Egypt. \\ Email: tareksaideg@yahoo.co.uk
}

Received January $2^{\text {nd }}, 2011$; revised March $7^{\text {th }}, 2011$; accepted April $11^{\text {th }}, 2011$.

\begin{abstract}
Organotin and organolead compounds were determined in sediments of the Suez Gulf. The concentrations of Tributyltin (TBT) ranged from 0.27 to 2.77 with an average value of $1.37 \mu \mathrm{g} \cdot \mathrm{g}^{-1}$; dry wt. However, the concentrations of dibutyltin (DBT) ranged from 0.07 to 2.27 with an average value of $0.58 \mu \mathrm{g}^{-1} \mathrm{~g}^{-1}$ dry wt. A significant correlation was found between TBT and DBT with $r=0.82,(p=0.05)$ indicating that the occurrence of DBT is mainly related to the degradation of TBT. Generally, the high concentration of TBT was attributed to shipping activity in harbours. In addition, Diphenyltin (DPhT) concentrations ranged from not detected to 2.09 with an average of $1.10 \mu \mathrm{g} \cdot \mathrm{g}^{-1} \mathrm{dry}$ wt. Antifouling agents, industrial discharge and the influence of sewage discharge are the main sources of pollution by DPhT compounds in Suez Gulf. On the other side, organolead $(\mathrm{OLC})$ concentrations ranged from 10.88 - 440.2 with an average of $168.7 \mathrm{ng} \cdot \mathrm{g}^{-1}$; dry wt. A significant setting of OLC recorded in sediments of Suez Gulf was mainly attributed to cars exhaust and/or spelling and direct evaporation of fuels.
\end{abstract}

Keywords: Organotin, Organolead, Sediment, Suez Gulf, Egypt

\section{Introduction}

Organometallic compounds have different toxicological behavior compared to that of nonorganic compounds of the respective elements. Under environmental conditions metal-carbon bonds of the elements $\mathrm{Sn}$ and $\mathrm{Pb}$ are stable [1]. Organotin (OT) compounds have a broad range of applications and they are among the most widely used organometallic chemicals. Monobutyltin (MBT) and dibutyltin (DBT) compounds are used as thermal and UV stabilizers of polyvinylchloride (PVC) and as catalysts in the production of polyurethane foams and silicones. Tributyltin (TBT) and triphenyltin (TPhT) have been used as antifouling agents in pleasure boats, large ships and vessels, harbor structures, and aquaculture nets, as well as agrochemicals and general biocides [2]. Various biological effects as a result of OTs exposure have been well documented. TBT, among OTs is of the most concern due to its direct introduction into the environment and its high toxicity; it has been shown that it was toxic to many embryonic and larval organisms even at low concentrations [3]. TBT compounds caused the reduction of mollusks growth [4], shell thickening in Pacific oysters [5] and imposex in gastropods [6-8]. Organotin compounds were measured in sediments of four different semi-en closed areas of the Mediterranean coast of Alexandria: the Eastern Harbor, Western Harbor, El-Max Bay and Abu-Qir Bay [9].

Due to the commercial trade activity inside the Western Harbor, in addition to the effect of wastes discharged from El Noubaria canal, it shows the highest concentrations of total tin $\left(6.34 \mu \mathrm{g} \cdot \mathrm{g}^{-1}\right.$ dry wt), dibutyl tin (1.63 $\mu \mathrm{g} \cdot \mathrm{g}^{-1}$ wet wt), tributyl tin $\left(0.33 \mu \mathrm{g} \cdot \mathrm{g}^{-1}\right.$; wet wt) and diphenyl tin $\left(1.06 \mu \mathrm{g} \cdot \mathrm{g}^{-1}\right.$; wet wt) compared with other locations.

During the past decade it became gradually recognized that exploring and monitoring the concentration levels of the various ionic organolead species in the environment would be of major importance for a double reason; to elucidate a possible bio-geochemical cycle of lead and to paint out possible adverse effects, on man and the environment, associated with the wide spread use of tetra alkyllead compounds (TAL; $\mathrm{PbR}_{4}, \mathrm{R}=$ methyl or ethyl) as antiknock agents in gasoline. Tetraethyllead (TEL) and tetramethyllead (TML) were produced world-wide as anti-knocking additives for gasoline to increase octane numbers. The use of leaded gasoline over almost one century caused a ubiquitous pollution of the environment 
with lead ions or alkyllead compounds [10]. Dialkyllead and trialkyllead, which are relatively soluble in water and considerably more stable than the initial compounds, is believed to be derived from anthropogenic sources such as effluent from alkyllead production plants as well as, naturally, through the slow degradation of tetraalkyllead in the environment. Degradation products, finally yielding inorganic lead, are either adsorbed on particulates, accumulated by organisms or recycled to the atmosphere by volatilization through methylation [11].

In spite of increasing activities which lead to the OMCs pollution along the Egyptian Red Sea coasts. These activities include transportation mainly through the Suez Canal, loading and unloading, transit area, industrial activities in the Suez Gulf, in addition to urban run-off and domestic wastes of costal towns distributed along the Red Sea coasts. The investigations of OMCs specially organotin and organolead in the Suez Gulf still need much more efforts to give us a clear picture of extent of pollution by these compounds. The aim of the present work was to assess the concentrations of different types of organotin and organolead species in sediment of Suez Gulf to provide information about their distribution and occurrence and elucidate their fate by using the most recent advances in the field of analytical chemistry.

\section{Materials and Methods}

\subsection{Study Area}

Suez Gulf is a narrow shallow water body covering an area of about 7,500 km $\mathrm{km}^{2}$ with $250 \mathrm{~km}$ long, $32 \mathrm{~km}$ width and $45 \mathrm{~m}$ average depth [12]. It is considered as the most polluted area in the Red Sea [13-16]. It is located between longitude $3250 \_$to $3^{\circ} 00_{-} \mathrm{E}$ and latitude $27^{\circ} 50_{-}$to $57^{\circ} 71$ N. It has $11 \mathrm{~km}$ as a proper transitional area at the Suez Bay-Suez Gulf and the width increases to $19 \mathrm{~km}$ at Ras Matarma and $45 \mathrm{~km}$ at Ras Abu Zenima. It is a transit area for ships passing to and from the Suez Canal. Moreover, several industries have been established along the western coastal such as refineries, fertilizer plant, power stations, and dry docks which are closed to Port Tawfiq region. Ten Stations were selected to cover the expected polluted sites due to industrial and other activities in the Suez Gulf (Figure 1).

\subsection{Sampling and Analyses}

Coastal sediment samples were collected three times from 10 stations in depths ranged from $4-6 \mathrm{~m}$ after tidal zone using a Hydro-Bios stainless-steel grab sampler during winter and kept frozen at $-20^{\circ} \mathrm{C}$, until analysis. The water content (WC) of each sample was determined

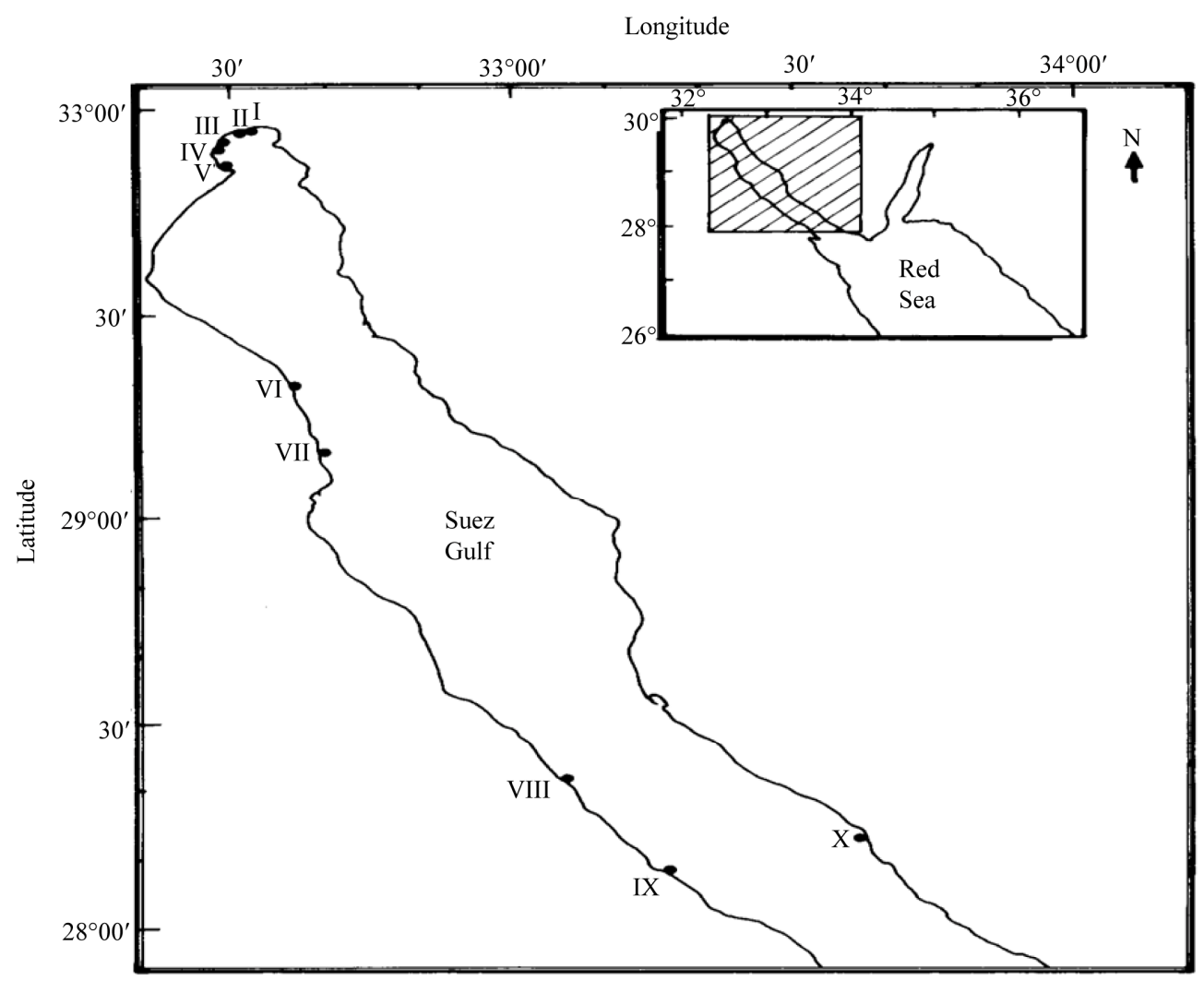

Figure 1. Sampling stations along the Suez Gulf. 
by drying a representative sample in an oven at $105^{\circ} \mathrm{C}$ overnight to a constant weight. Moreover, organic carbon was determined using acid/dichromate titration method [17]. Grain- size analysis was carried out using the conventional method [18]. About $30 \mathrm{~g}$ of washed and quartered dried sample was subjected to the combined technique of dry sieving and pipette analysis. Porosity $\%$ was calculated according to the equation Porosity = $(\mathrm{WC} / 1.02) /[(1-\mathrm{WC}) / 2.64+\mathrm{WC} / 1.02]$ [19]. Total tin and total lead compounds in sediment samples were determined according to UNEP/IAEA [20]. $0.5 \mathrm{~g}$ of dry sediment sample was completely digested in Teflon vessels using a mixture of $\mathrm{HNO}_{3}$, $\mathrm{HF}$ and $\mathrm{HClO}_{4}(3: 2: 1 \mathrm{~V} / \mathrm{V})$ and triplicate digestions were made for each sample. The final solution was diluted to $25 \mathrm{ml}$ with distilled de-ionized water. All digested solutions were analyzed by using inductively coupled plasma instrument; ICP (Spectro Analytical instruments Gmbh, Boschstra Be 10, D-47533 Kleve/Germany, 7431/95). Accuracy and precision were checked by using reference material (SD-M-2/IM marine sediment) provided by the National Research Council of Canada (Analytical results of the quality control samples indicated a satisfactory performance of heavy metals determination within the range of certified values with $90.4 \%-97.5 \%$ recovery for studied metals. Organotin compounds; TBT, DPhT and DBT were determined according to Tsuda. et al. [21] as follows; ten grams of sediment was placed into $500 \mathrm{ml}$ separating funnel, and extracted for $30 \mathrm{~min}$ with $50 \mathrm{ml}$ ethyl acetate after adding $50 \mathrm{ml}$ water and $5 \mathrm{ml} \mathrm{HCl}$. The mixture was centrifuged at $2500 \mathrm{rpm}$ for $5 \mathrm{~min}$ and $30 \mathrm{ml}$ of organic layer were transferred to $50 \mathrm{ml}$ round-bottom flask. The organic layer was evaporated nearly to dryness $(0.1 \mathrm{ml})$ in vacuum at $40^{\circ} \mathrm{C}$. The residue was dissolved in $1 \mathrm{ml}$ ethanol, $2 \mathrm{ml}$ hydrogenation reagent $\left(1 \mathrm{~g}\right.$ of $\mathrm{NaBH}_{4}$ dissolved in $40 \mathrm{ml}$ ethanol) was added with shaking, and let for standing for $10 \mathrm{~min}$ at room temperature. Five $\mathrm{ml}$ of water was added to the reaction mixture, shacked slightly, and transferred to $50 \mathrm{ml}$ separating funnel. The flask was rinsed with $5 \mathrm{ml}$ portions of water, and transferred to the funnel then extracted for $5 \mathrm{~min}$ with $5 \mathrm{ml}$ hexane after adding of $5 \mathrm{~g} \mathrm{NaCl}$. Hexane was passed through silica gel column to elute butyltin hydrides. The first $20 \mathrm{ml}$ was collected in round-bottom flask, evaporated to about $2 \mathrm{ml}$ under reduced pressure at $40^{\circ} \mathrm{C}$. (The concentrate was transferred into $5 \mathrm{ml}$ gradual test tube, rinsing flask with hexane, and the volume was adjusted to $1 \mathrm{ml}$ under nitrogen stream in $40^{\circ} \mathrm{C}$ dry bath. The final extract was then injected into gas chromatograph/electron capture detector, GC/ECD (HP 5890 II). The chromatographic column was HP-5 capillary column $(30 \mathrm{~m} \times 0.32 \mathrm{~mm} \times$ $0.25 \mu \mathrm{m}) ; 5 \%$ diphenyl and $95 \%$ dimethyl polysiloxane, non-polar 60 to $325^{\circ} \mathrm{C}$ ) with $\mathrm{N}_{2}$ as carrier gas with flow rate of $2 \mathrm{ml} / \mathrm{min}$. The injection port and detector line were at 300 and 310 , respectively. The column was programmed from $80^{\circ} \mathrm{C}$ for $3 \mathrm{~min}$ to a final $310^{\circ} \mathrm{C}$ for $8 \mathrm{~min}$ at a rate $5^{\circ} \mathrm{C} / \mathrm{min}$.

Organolead compounds (tri-alkyllead and tetraalkyllead) were determined according to Chau et al. [22] as follows; about $5 \mathrm{~g}$ of sediment samples was extracted in a capped glass vial with $3 \mathrm{ml}$ benzene after addition of 10 $\mathrm{ml} \mathrm{H}_{2} \mathrm{O}, 6 \mathrm{~g} \mathrm{NaCl}, 1 \mathrm{~g}$ potassium iodide, $2 \mathrm{~g}$ sodium benzoate, $3 \mathrm{ml}$ of $0.5 \mathrm{~mol} / 1$ sodium diethyldithiocarbamate (NaDDTC) and $2 \mathrm{~g}$ coarse glass beads (20 - 40 mesh) with stirring for $2 \mathrm{~h}$ in mechanical Shaker. After centrifugation of the mixture, a measured aliquot $(1 \mathrm{ml})$ of benzene was taken for butylation. Derivatization was carried out by adding $0.5 \mathrm{ml}$ butyl Grignard reagent (butyl magnesium chloride; Sigma Aldrich, USA) to the sample. The mixture was gently shacked for $10 \mathrm{~min}$, and washed with $5 \mathrm{ml}$ of $0.5 \mathrm{M}$ sulfuric acid to destroy the excess of Grignard reagent. About $2-3 \mathrm{ml}$ of the organic phase was pipetted into a small vial and dried with anhydrous sodium sulfate. Appropriate amounts $(3-5 \mu \mathrm{l})$ were injected into gas chromatograph/flame ionization detector (GC/FID). The sample extract was introduced directly to the chromatographic column by micro-syringe. The chromatographic column was HP-5 capillary column $(30 \mathrm{~m} \times 0.32 \mathrm{~mm} \times 0.25 \mu \mathrm{m}) ; 5 \%$ diphenyl and $95 \%$ dimethyl polysiloxane, non-polar $\left(60\right.$ to $\left.325^{\circ} \mathrm{C}\right)$ with $\mathrm{N}_{2}$ as carrier gas with flow rate of $2 \mathrm{ml} / \mathrm{min}$. The injection port and detector line were at 150 and $200^{\circ} \mathrm{C}$, respectively. The column was programmed from $60^{\circ} \mathrm{C}$ to $200^{\circ} \mathrm{C}$ at a rate $8^{\circ} \mathrm{C} / \mathrm{min}$.

\subsection{Method Validation and Quality Control Studies}

Method validation and quality control samples were done using standard solutions and applying the computerized 4.3 quality system provided by DANIDA from VKI. Two natural samples were analyzed in duplicate in each of six batches of samples after spiking by a known concentration of the standard solution. The same two natural samples were analyzed without spiking. The highest and lowest percentages of recovery for spiked samples were used to determine the accuracy which ranged between 90 and $105 \%$.

\section{Results}

\subsection{Grain Size}

A thorough sight on data of Table 1, indicated that sandy sediments are dominant at most of the area of investigation. The mean size of sediments ranges from $2.03 \varnothing$ at station II (El Zaitia Harbour) to $0.19 \varnothing$ at station VII (Ras Gharib), i.e. from fine to course sand. However, sorting 
values vary from 0.65 to 1.47 (i.e. from moderately well sorted to poorly sorted) reflected unstable condition in the Suez Gulf. Folk (18) stated that the most the skewness value departs from zero, the greatest the degree of asymmetry. About $70 \%$ of the samples of investigation are positively skewed (i.e. finely skewed), this clearly indicates the asymmetry of sediments in the Suez Gulf. The same is true for Kurtosis values ranging from 0.45 at station III (El Kabanon) to 1.11 at station V (Adabiya Port).

\subsection{Water Percent and Porosity Percent}

Water percent is an important factor in controlling the early digenetic processes of sediments. It affects the rate of reactions particularly, the Redox processes, $\mathrm{pH}$ and the amount of organotin compounds that may be trapped due to their hydrophobic characteristics. Water percent reflects the ability of sediments to hold water molecules between their particles, which are mainly a function of particle size and mineral composition [23].

Water percent of the Suez Gulf sediments is ranged between $13.55 \%$ and $54.54 \%$. The maximum absolute value of $54.54 \%$ was observed at station II; while the minimum absolute value $13.55 \%$ was observed at station
VIII, this reflects the effect of the nature of coarse sandy sediment at this station. The porosity ranged from $6.11 \%$ at station VII to $37.79 \%$ at station I (Table 2).

\subsection{Total Organic Carbon (TOC)}

Organic carbon contents ranged from $0.01 \%$ to $2.95 \%$ with an average value of $0.67 \%$ (Table 2 ). The maximum values were observed at stations I and II, and this may be due to the influence of industrial wastewater produced by discharging about 93 tones of heavy petroleum fractions annually into the bay from two large refineries (Suez petroleum and El Nasr petroleum companies [24]. Moreover, El-Zeitia Harbor station (II) considered one of the heaviest loading and unloading operations of oil tan- kers in the world [25]. On the other hand, it polluted by the discharge of both agriculture and domestic wastes from cities distributed along the Suez Canal. (A good correlation between TOC and water contents in sediment of the Suez Gulf was observed $r=0.82(p=$ $0.05)$. The minimum absolute value of $0.01 \%$ was observed at station VI revealed that this station is not subjected to the influence of industrial or domestic discharge.

Table 1. Grain size analysis of sediment samples collected from Suez Gulf during 2005.

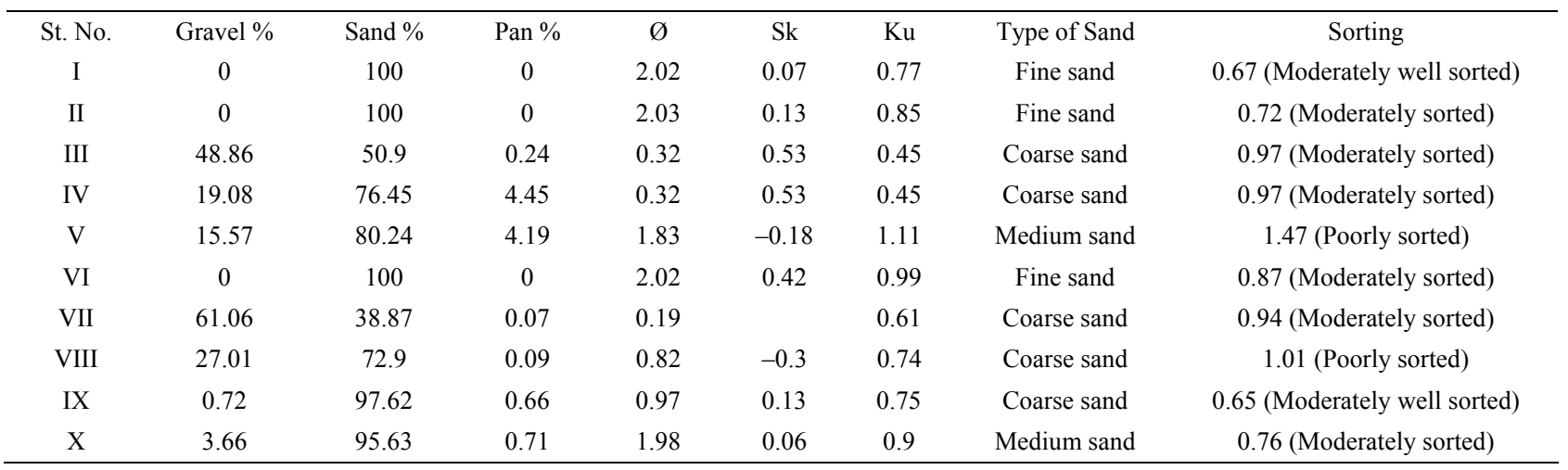

W: water percent, P: porosity, TOC: total organic carbon, TC: total carbonate, Si: silicon content, * cited from Shreadah et al. [42].

Table 2. Physico-chemical parameters of the sediment samples collected from Suez Gulf during 2005.

\begin{tabular}{|c|c|c|c|c|c|}
\hline I & 43.06 & 37.79 & 1.65 & 50 & 12 \\
\hline II & 54.54 & 26.92 & 2.95 & - & - \\
\hline III & 37.88 & 22.53 & 0.35 & 54 & 13.2 \\
\hline IV & 31.12 & 17.26 & 0.35 & 42 & 22.5 \\
\hline $\mathrm{V}$ & 38.76 & 23.25 & 0.80 & 60 & 9.9 \\
\hline VI & 14.21 & 6.460 & 0.01 & 66 & 11.7 \\
\hline VII & 17.98 & 8.580 & 0.10 & 28 & 31.8 \\
\hline VIII & 13.55 & 6.110 & 0.30 & 22 & 26.7 \\
\hline IX & 21.03 & 10.41 & 0.05 & 42 & 19.4 \\
\hline $\mathrm{X}$ & 33.84 & 19.32 & 0.20 & 21 & 10.6 \\
\hline
\end{tabular}

W: water percent, P: porosity, TOC: total organic carbon, TC: total carbonate, Si: silicon content, * cited from Shreadah et al. [42]. 


\subsection{Total Tin and Total Lead Compounds}

Concentrations of total lead ranged from 25 to $81\left(\mu \mathrm{g} \cdot \mathrm{g}^{-1}\right.$; dry wt) in the area of study (Figure 2). High values were measured at stations I, V, VIII and X. This may be due to industrial and domestic effluents as well as the atmospheric deposition besides the contribution of $\mathrm{Pb}$ from the leaded petrol in outboard boat engines and oil refineries in this area. Comparing concentrations measured in the present study to those observed by previous workers, one can easily find that the concentrations of $\mathrm{Pb}$ increased significantly from 1992 to 1998 then decreased during 2002 and increased again during 2005 (Table 3). This may reflect that $\mathrm{Pb}$ is strongly affected by the industrial developments and increasing human activities in the Suez Gulf. The concentrations of $\mathrm{Pb}$ were observed to be

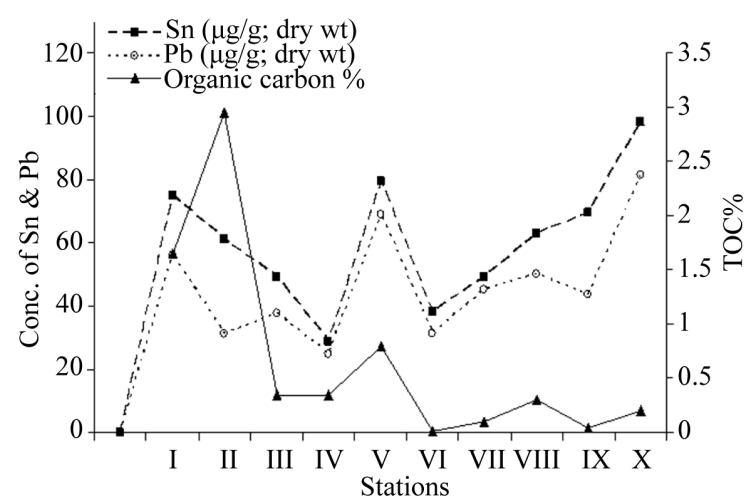

Figure 2. Relationship between total lead and tin concentrations with organic carbon \% for sediment samples collected from Suez Gulf during 2005.

Table 3. Comparison between total lead and total Tin concentrations $\left(\mu \mathrm{g} \cdot \mathrm{g}^{-1}\right.$; dry wt) in sediments of the Suez Gulf during 2005 and those recorded by others.

\begin{tabular}{lcc}
\hline Area & Range $\left(\mu \mathrm{g} \cdot \mathrm{g}^{-1}\right.$, dry wt) & References \\
\hline & $\mathrm{Pb}$ & \\
Suez Gulf (2005) & $25-81$ & Present study \\
Suez Bay (2005) & $25-69$ & Present study \\
Suez Bay (1993-1994) & $14-28$ & {$[26]$} \\
Suez Bay (1997-1998) & $22-91$ & {$[27]$} \\
Suez Bay (2002) & $20-40$ & {$[28]$} \\
Suez Gulf (1999) & $71-100$ & {$[29]$} \\
Background level & $20-30$ & {$[30]$} \\
& Sn & Present study \\
Suez Gulf & $4-30$ & {$[9]$} \\
Western Harbor, Egypt & $3-6$ & {$[31]$} \\
Riade Aroua, Spain & $5-21$ & {$[32]$} \\
Gipuzloa, Spain & $11-113$ & {$[33]$} \\
Gulf of Codiz, Spain & $8-24$ & \\
\hline
\end{tabular}

higher than the background level $\left(20-30 \mu \mathrm{g} \cdot \mathrm{g}^{-1}\right)$ [30].

Total tin concentrations ranged between 4 and 30 $\left(\mu \mathrm{g} \cdot \mathrm{g}^{-1}\right.$; dry wt) with an average value of $14 \mu \mathrm{g} \cdot \mathrm{g}^{-1}$. The maximum value of $30 \mu \mathrm{g} \cdot \mathrm{g}^{-1}$ was observed at station II (El Zeitia), this station is affected mainly by heavy oil processing and ships discharge containing organotin compounds as antifouling paints. On the other hand, the high value of $25 \mu \mathrm{g} \cdot \mathrm{g}^{-1}$; dry wt measured at station IX; was attributed to the fact that this area is subjected to high oil field activities distributed at Ras Shukhir, in addition to the presence of a large amount of decayed algae. Algae can accumulate inorganic tin compounds and ultimately remove tin from water and release it to the atmosphere by the formation and release tetramethyltins [34]. It was found that total tin concentrations in marine macro algae varied between 0.5 and $101 \mathrm{mgk}^{-1}$; dry wt and demonstrated that most species of aquatic flora bio-concentrate tin from seawater [35].

Minimum value of $4 \mu \mathrm{g} \cdot \mathrm{g}^{-1}$ was detected at station IV (NIOF) and revealed that this station is not subjected to the influence of industrial or sewage discharge i.e., far from inputs of tin compounds. Lin and Chen [36] stated that grain size was found to be one of the major factors controlling heavy metals distribution in sediments. The sediments in our area of investigation were mainly sand, thus the total metal concentrations were not grain size controlled with $r=0.4$ between total metal concentration and mean size of each sediment sample. Total tin concentrations were found to have a positive significant correlation with organic carbon content with $r=0.64$; $(p=$ $0.05)$. Figure 2 shows that there is a correlation between TOC and both $\mathrm{Sn}$ and $\mathrm{Pb}$ particularly in stations $\mathrm{I}$ toV and this related to anthropogenic sources especially in stations III and IV. However, a weak correlation was observed for stations VI to $\mathrm{X}$ reflecting low content of organic carbon, i.e., low pollution index for such stations especially at stations VI and IX. Table 4 shows the comparison between total tin concentrations in the present study with other studies at similar areas. We found that the concentration of total Sn measured along the Suez Gulf were comparable with that observed in Riade Aroua and Gulf of Codiz, Spain. However, it was higher than that observed in Gipuzloa, Spain and Western Harbor, Egypt (Table 3).

\subsection{Organotin Compounds}

\subsubsection{Tributyltin (TBT) Species}

Concentrations of TBT in the investigated area ranged between 0.27 to $2.77 \mu \mathrm{g} \cdot \mathrm{g}^{-1}$; dry wt with an average value of $1.4 \mu \mathrm{g} \cdot \mathrm{g}^{-1}$ (Table 4). It is clear that TBT is the predominant species of OTC with a ratio to total OT species ranged from 20 to $75 \%$. The maximum value of 2.8 


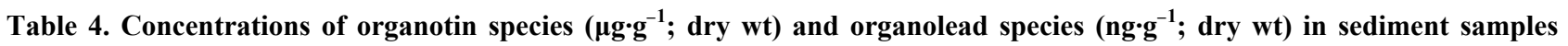
collected from the Suez Gulf during 2005.

\begin{tabular}{cccccccccc}
\hline St. & TBT & DBT & DPhT & TOT & $\mathrm{Et}_{4} \mathrm{~Pb}$ & $\mathrm{Me}_{4} \mathrm{~Pb}$ & $\mathrm{Et}_{3} \mathrm{~Pb}$ & $\mathrm{Me}_{3} \mathrm{~Pb}$ & $\mathrm{TOL}$ \\
\hline I & $0.51 \pm 0.02$ & $0.19 \pm 0.02$ & $1.32 \pm 0.03$ & 2.02 & $13.58 \pm 0.22$ & $19.30 \pm 0.41$ & $126.59 \pm 0.51$ & $13.59 \pm 0.36$ & 173.06 \\
II & $2.77 \pm 0.25$ & $2.27 \pm 0.12$ & $2.09 \pm 0.04$ & 7.13 & $4.88 \pm 0.11$ & $15.09 \pm 0.14$ & $22.44 \pm 0.71$ & $10.78 \pm 0.59$ & 53.19 \\
III & $0.27 \pm 0.03$ & $0.08 \pm 0.01$ & $0.98 \pm 0.03$ & 1.34 & $71.27 \pm 0.27$ & $34.06 \pm 0.10$ & $3.59 \pm 0.05$ & $20.70 \pm 0.55$ & 129.62 \\
IV & $0.81 \pm 0.09$ & $0.07 \pm 0.01$ & $0.89 \pm 0.05$ & 1.77 & $74.48 \pm 1.23$ & $210.74 \pm 1.87$ & $4.57 \pm 0.27$ & $150.73 \pm 0.65$ & 440.52 \\
V & $2.19 \pm 0.13$ & $1.32 \pm 0.03$ & $1.44 \pm 0.05$ & 4.95 & $35.60 \pm 0.50$ & $203.38 \pm 0.58$ & $25.42 \pm 0.86$ & $162.49 \pm 0.37$ & 426.89 \\
VI & $1.50 \pm 0.10$ & $0.48 \pm 0.03$ & $<\mathrm{DL}$ & 1.98 & $<\mathrm{DL}$ & $47.13 \pm 0.61$ & $<\mathrm{DL}$ & $35.13 \pm 0.41$ & 82.26 \\
VII & $0.35 \pm 0.04$ & $0.11 \pm 0.01$ & $0.82 \pm 0.03$ & 1.28 & $0.59 \pm 0.03$ & $2.27 \pm 0.14$ & $3.18 \pm 0.20$ & $4.84 \pm 0.16$ & 10.88 \\
VIII & $1.11 \pm 0.18$ & $0.22 \pm 0.01$ & $0.99 \pm 0.02$ & 2.33 & $4.04 \pm 0.05$ & $63.96 \pm 0.75$ & $1.23 \pm 0.08$ & $61.16 \pm 0.27$ & 130.38 \\
IX & $1.87 \pm 0.18$ & $0.42 \pm 0.02$ & $1.13 \pm 0.05$ & 3.42 & $42.31 \pm 0.12$ & $23.90 \pm 0.78$ & $8.38 \pm 0.33$ & $13.44 \pm 0.49$ & 88.02 \\
X & $2.31 \pm 0.20$ & $0.60 \pm 0.05$ & $1.33 \pm 0.05$ & 4.25 & $3.37 \pm 0.25$ & $13.97 \pm 0.23$ & $121.49 \pm 0.65$ & $12.94 \pm 0.31$ & 151.77 \\
Av. & 1.37 & 0.58 & 1.1 & 3.05 & 25.01 & 63.38 & 31.69 & 48.58 & 168.66 \\
\hline
\end{tabular}

$<\mathrm{DL}$ : below the detection limit, $\mathrm{Av} .=$ average value for triplicate analyses, $\left.\mathrm{TOT}=\mathrm{Sum}(\mathrm{TBT}+\mathrm{DBT}+\mathrm{DPhT}), \mathrm{TOL}=\mathrm{Sum}_{(\mathrm{Et}} \mathrm{Pb}_{4}+\mathrm{Me}_{4} \mathrm{~Pb}+\mathrm{Et}_{3} \mathrm{~Pb}+\mathrm{Me}_{3} \mathrm{~Pb}\right)$.

$\mu \mathrm{g} \cdot \mathrm{g}^{-1}$ was observed at station (II); Zeitia Harbor which has high contents of total organic carbon with $2.95 \%$. It has been reported that the organic carbon content of sediments affects the bioavailability and toxicity of TBT i.e. sediments with high concentration of organic matter may act as sink for TBT [37,38]. In addition it situated near the shipyard dry dock in which TBT compounds are used in painting the hulls of new vessels and on older vessels during dry docking. The average TBT content in marine paints was about 4\%, and approximately 1200 tons of TBT was applied annually to ships hulls [39]. On the meantime, high concentrations of TBT were also found at stations V, VI, IX and X where, station V (El Adabiya port) is affected by loading and unloading activities. In addition to the wastes of some industries such as vegetable oil factories and chemical industries near this station and wastes discharged from Attaqa power station, at which TBT compounds are used as a biocide for cooling waters. Station VI (El Sukhna) is considered as transit area of ships passing through the Suez Canal. It was reported that, during 3-days stay inside a harbor, a commercial ship, leaching TBT at the constant leach rate, can release more than $200 \mathrm{~g}$ TBT into water [40]. However, if freshly painted, this amount can reach $600 \mathrm{~g}$, which can result in a dissolved TBT contamination of the surrounded water ranging between 100 and 200 or about $600 \mathrm{ng} \cdot \mathrm{Snl}^{-1}$, respectively. Station IX (Ras Shukier) is a large center for collection and shipment of oil from several oil fields including off shore wells. The high value of TBT observed at station (X); El Tour was attributed to the high intensity of fishing boats activities which use TBT in antifouling paints. on the other hand, the relatively low concentration of $0.27 \mu \mathrm{g} \cdot \mathrm{g}^{-1}$ dry wt found at station III+ is mainly due to the coarse sand nature of sediment. A good significant correlation was observed between TBT and mean size (Ø) with $r=0.67(p=0.05)$. Therefore, TBT accumulated in sediments of the Suez Gulf was affected by grain size.

It has been reported that The Australian sediment quality guidelines for TBT are $5 \mathrm{ng} \cdot \mathrm{g}^{-1}$ and $70 \mathrm{ng} \cdot \mathrm{g}^{-1}$ for low and high threshold values [41]. The concentrations of TBT in sediment samples from 10 stations along the Suez Gulf were found to be higher than the highest threshold value, suggesting these sediments may pose a threat to a benthic biota. Moreover, high levels of TBT in Suez Gulf sediments reflects its widespread contamination and could be an indicative of the continuing usage of TBT- based antifouling paints on ship hulls.

Shereadah et al. [42] investigated the mineralogical composition of surficial sediments along the Egyptian Red sea coast during 2006. They indicated that in Suez Gulf, the average value of total carbonate (TC \%) $=42 \%$ while the average value of $\mathrm{Si} \%=19.4$ (Table 2). This indicated that the composition of sediment in our area of investigation is mainly carbonate meaning that sediments are weak adsorbents and prone to digenesis and redissolution. However, the relatively high concentrations of TBT recorded in sediments of the Suez Gulf result from renewal source of contamination by such compounds rather that adsorption to sediment.

Dowson et al. [37] have introduced a classification for TBT concentrations in sediments, characterizing concentrations below $3 \mathrm{ngg}^{-1}$ as uncontaminated, $3-20 \mathrm{ng} \cdot \mathrm{g}^{-1}$ as light contaminated, $20-100 \mathrm{ng} \cdot \mathrm{g}^{-1}$ as moderately contaminated, 100 - 500 as highly contaminated and above $500 \mathrm{ng} \cdot \mathrm{g}^{-1}$ as grossly contaminated. Following this scheme, 
the sampled surface sediments in the Suez Gulf are considered as highly to grossly contaminate.

\subsubsection{Dibutyltin (DBT) Species}

Dibutyltin concentrations varied from 0.07 to $2.27 \mu \mathrm{g} \cdot \mathrm{g}^{-1}$; dry wt with an average concentration of $0.58 \mu \mathrm{g} \cdot \mathrm{g}^{-1}$; dry wt. (Table 4). A significant correlation with $r=0.82(p=$ $0.05)$ was found between the concentration of TBT and DBT reflecting the degradation of TBT as a main source of DBT in the Suez Gulf. The maximum value of DBT was observed at station (II) due to 1) the direct emission or the degradation of TBT to DBT at surface water as mentioned by [43-49] and microbial degradation of TBT to DBT and MBT in oxic and anoxic sediments [50], 2) high value of organic carbon content $2.95 \%$ in sediments. The minimum absolute value of DBT $0.07 \mu \mathrm{g} \cdot \mathrm{g}^{-1}$; dry wt at stations (III and IV) may be attributed to the type of sediment (coarse sand).In general, the concentration of TBT was greater than DBT in sediments of the Suez Gulf and the TBT/DBT ratio showed large variation from 1.22 to 11.20. High TBT/DBT ratio may be attributed to recent input of TBT and/or to low degradation of TBT to DBT into these stations. It is known that TBT degradation rates in sediment are slower than in water column, particularly in anaerobic conditions. The half life of TBT in sediments is in the range of years rather than days or weeks in the water column [51]. Although abiotic degradation occurs, the process remains less important than biological action [52]. Microbial degradation of TBT to DBT and MBT takes days to weeks in water, years in oxic sediments and more than that in anoxic sediments [50]. The degradation products have generally been assumed to be less toxic than TBT because they are less lipophilic. Furthermore, bacterial communities degrading TBT might be dependent on salinity and other environmental factors [53].

\subsubsection{Diphenyltin (DPhT) species}

A thorough sight on data of Table 5 indicated that diphenyltin (DPhT) species showed relatively high con- centrations at the stations along the Suez Gulf. This may be due to the influence of sewage and industrial (refineries and textile companies) discharge. DPhT concentrations in the Suez Gulf were $<2.09 \mu \mathrm{g} \cdot \mathrm{g}^{-1}$; dry wt with an average concentration of $1.09 \mu \mathrm{g} \cdot \mathrm{g}^{-1}$ dry wt. The maximum absolute value of DPhT $2.09 \mu \mathrm{g}^{\circ} \mathrm{g}^{-1}$; dry wt observed at station (II), is due to the use of triphenyltin as antifouling agents in ship paints and discharged of the agricultural wastewater from the Suez Canal. According to Odoyemi et al. [54] high concentrations of butyltin and phenyltin derivatives are possibly due to using them in agricultural and industrial activities or high sorption affinity onto soils. However, the occurrence of butyltin and phenyltin derivatives in an aquatic environment could be a result of sewage sludge and high degradation of triphenyltin to phenyltin derivatives (mono and di phenyltin) [55].

Previous studies revealed that TBT is toxic to aquatic biota at concentrations of $>2 \mathrm{ng} \cdot 1^{-1}$ [56]. Regarding to the production, usage, accumulation, and toxicity of organotin compounds. Based on the results obtained from the present study, we can conclude that the prohibition of using organotin in antifouling paints is an effective action for both the protection and conservation of marine life. Furthermore, detecting the average concentration values $1.37,0.58$ and $1.10\left(\mu \mathrm{g} \cdot \mathrm{g}^{-1}\right)$ for TBT, DBT, and $\mathrm{DPhT}$, respectively in our investigated areas proves a real need for enforcing the existing regulations.

\subsection{Organolead Compounds (OLC)}

Table 4 shows the concentrations of four OLC species in sediment samples, collected from the Suez Gulf. The concentrations ranged from not detected - 74.48, 2.270 210.7, not detected -126.6 and $4.840-162.5 \mathrm{ng} \cdot \mathrm{g}^{-1}$; dry wt, for $\mathrm{Et}_{4} \mathrm{~Pb}, \mathrm{Me}_{4} \mathrm{~Pb}, \mathrm{Et}_{3} \mathrm{~Pb}^{+}$and $\mathrm{Me}_{3} \mathrm{~Pb}^{+}$, respectively. However, the concentration of total OLC ranged from $10.88-440.2 \mathrm{ng} \cdot \mathrm{g}^{-1}$; dry wt. The results of OLC species indicated the significant setting of OLC into sediments. It has been reported that $\mathrm{Et}_{4} \mathrm{~Pb}$ species is expected to be

Table 5. The correlation matrix for different organic pollutants recorded in different stations of the investigated area during 2005.

\begin{tabular}{|c|c|c|c|c|c|c|c|}
\hline Parameter & TBT & DBT & $\mathrm{DPhT}$ & $\mathrm{Et}_{4} \mathrm{~Pb}$ & $\mathrm{Me}_{4} \mathrm{~Pb}$ & $\mathrm{Et}_{3} \mathrm{~Pb}$ & $\mathrm{Me}_{3} \mathrm{~Pb}$ \\
\hline TBT & 1.00 & & & & & & \\
\hline DBT & 0.82 & 1.00 & & & & & \\
\hline DPhT & 0.50 & 0.68 & 1.00 & & & & \\
\hline $\mathrm{Et}_{4} \mathrm{~Pb}$ & -0.31 & -0.28 & -0.02 & 1.00 & & & \\
\hline $\mathrm{Me}_{4} \mathrm{~Pb}$ & 0.05 & 0.03 & -0.04 & 0.55 & 1.00 & & \\
\hline $\mathrm{Et}_{3} \mathrm{~Pb}$ & 0.13 & 0.01 & 0.36 & -0.29 & -0.26 & 1.00 & \\
\hline $\mathrm{Me}_{3} \mathrm{~Pb}$ & 0.07 & 0.05 & -0.03 & 0.48 & 0.99 & -0.26 & 1.00 \\
\hline
\end{tabular}


absorbed onto suspended solids and sediments in water column [57]. Table 4 shows relatively high concentrations of tetraalkyllead in sediments of the Suez Gulf. This is attributed to the presence of renew sources and the high density of these compounds to sink and spread along the stream bottom. On the other word, the concentration of $\mathrm{Me}_{4} \mathrm{~Pb}$ is higher than $\mathrm{Et}_{4} \mathrm{~Pb}$, this reflecting the biomethylation of inorganic lead or organolead cations to tetramethyllead [58]. In addition, $\mathrm{Et}_{4} \mathrm{~Pb}$ is more sensitive to photochemical process than $\mathrm{Me}_{4} \mathrm{~Pb}$ [59], which lead to higher decomposition of $\mathrm{Et}_{4} \mathrm{~Pb}$ in water column. Triethyllead species show a positive correlation with mean size $(\varnothing)$ with $r=0.57(p=0.05)$.

Maximum concentrations of 440.2 and $426.89 \mathrm{ng} / \mathrm{g}$; dry wt of OLC were recorded at stations IV and V, respectively. These stations are located near busy roads of the Suez city at which antiknock organolead compounds are emitted from incomplete fuels combustion through cars exhaust. Besides, spilling and direct evaporation are possible sources of OLC pollution. In addition, water circulation could affect the transport mechanism of OLC, where there is a persistent anti-clock wise circulation in the Bay causing more pollution in the western side. Insignificant correlation was calculated between total $\mathrm{Pb}$ $\left(\mu \mathrm{g} \cdot \mathrm{g}^{-1}\right.$ dry wt) and total OLC $\left(\mathrm{ng} \cdot \mathrm{g}^{-1}\right.$; dry wt) with $r=$ $0.13(p=0.05)$ in sediment samples, reflecting the influence of different sources of lead pollution on these stations. Table 5 shows that a significant correlation is recorded between TBT and DBT, DBT and DPhT, $\mathrm{Me}_{4} \mathrm{~Pb}$ and $\mathrm{Me}_{3} \mathrm{~Pb}$ with $r=0.82,0.68$ and 0.99 respectively.

\section{REFERENCES}

[1] H. Siegl and A. Sigel, "Biological Properties of Metal Alkyl Derivatives,” Dekker, New York, 1993.

[2] K. Fent, "Ecotoxicology of Organotin Compounds," Revised Marine Toxicology, Vol. 26, 1996, pp. 117-121.

[3] G. W. Bryan and P. E. Gibbs, "Impacts of Low Concentrations of Tributyltin (TBT) on Marine Organisms," In: M. C. Newman and A. W. McIntosh, Eds., Metal toxicology, Concepts and applications, Academic Press, London, 1991.

[4] M. H. Salazar and S. M. Salazar, "Assessing Site-Specific Effects of TBT Contamination with Mussel Growth Rates," Marine Environment Research, Vol. 32, No. 1-4, 1991, pp. 131-150. doi:10.1016/0141-1136(91)90038-A

[5] C. Alzieu, J. Sanjuan, J. P. Deltreil and B. Borel, "Tin Applied," Organometallic Chemistry, Vol. 17, 1986, pp. 81-105.

[6] T. Horiguchi, H. Shiraishi, M. Shimizu and M. Morita, "Imposex and Organotin Compounds in Thais Clavigera and T. Bronni in Japan," Journal of Marine Biolology, Vol. 74, 1994, pp. 651-669.

doi:10.1017/S002531540004772X
[7] A. Siah, J. Pellerin, J. C. Amiard, E. Pelletier and L. Viglino, "Delayed Gamesomeness and Progesterone Levels in Soft-Shell Clams (Mya Arenaria) in Relation to in Situ Contamination to Organotins and heAvy Metals in the St. Lawrence River," Comparative Biochemistry and Physiology Part C: Toxicol. Pharm., Canada, 2003.

[8] J. L. Gomez-Ariza, M. M. Santos, E. Morales, I. Giraldez, D. Sanchez-Rodas and N. Vieira, "Organotin Contamination in the Atlantic Ocean off the Iberian Peninsula in Relation to Shipping," Chemosphere, Vol. 64, No. 7, 2006, pp. 1100-1108.

doi:10.1016/j.chemosphere.2005.11.068

[9] M. A. Shreadah, T. O. Said, A. M. Younis and R. S. Farag, "Speciation of Organotin Compounds in Sediments of Semi-Closed Areas along the Mediterranean Coast of Alexandria," Chemistry and Ecology, Vol. 22, No. 5, 2006, pp. 395-404. doi: $10.1080 / 02757540600917443$

[10] C. Gallert and J. Winter, "Bioremediation of Soil Contaminated with Alkyllead Compounds," Water Research, Vol. 36, No. 12, 2002, pp. 3130-3140. doi:10.1016/S0043-1354(01)00543-7

[11] Y. K. Chau, P. T. S. Wong, G. A. Bengert, J. L Dunn and B. Glen, "Occurrence of Alkyllead Compounds in the Detroit and St Clair Rivers," Journal of Lakes Research, Vol. 11, No. 4, 1985, pp. 13-19.

[12] T. S. Murty and M. T. El-Sabh, "Weather System, Storm Surges and Sea State in the Red Sea and the Gulf of Aden," Proceeding Symposium on Coral Reef Environment, Red Sea, Jeddah, KSA, 1984.

[13] T. O. Said, "Analytical Determination of Dissolved Petroleum Components in Seawater Using Coupling System (GC-MS)," Ph.D. Thesis, Mansoura University, Egypt, 1996.

[14] A., Khaled, A. El-Nemer and A. El-Sikaily, "Contamination of Coral Reefs by Heavy Metals along the Egyptian Red Sea Coast," Bulletin Environmental Contamination and Toxicology, Vol. 71, No. 3, 2003, pp. 577-584. doi:10.1007/s00128-003-8751-y

[15] A. El Sikaily, A. Khaled, A. El-Nemer, T. O. Said and A. M. A. Abdullah, "Polycyclic Aromatic Hydrocarbons and Aliphatics in the Coral Reef Skeleton of the Egyptian Red Sea Coast," Bulletin Environmental Contamination and Toxicology, Vol. 71, No. 6, 2003, pp. 1252-1259. doi:10.1007/s00128-003-8736-X

[16] A. El Sikaily, A. Khaled and A. El-Nemer, "Heavy Metals Monitoring Using Bivalves from Mediterranean Sea and Red Sea," Environmental Monitoring Assessment, Vol. 98, No. 1-3, 2004, pp. 41-58. doi:10.1023/B:EMAS.0000038178.98985.5d

[17] APHA-AWWA-WEF, "Standard Methods for the Examination of Water and Wastewater," 18th Edition, Washington DC, 1992.

[18] R. L. Folk, "Petrology of Sedimentary Rocks," Hemphill, Austin, 1974.

[19] P. D. Jackson, D. Taylor Smith and P. N. Stanford, "Resistively-Porosity-Particle Shape-Relationships for Ma- 
rine Sands," Geophysics, Vol. 43, No. 6, 1978, pp. 1250-1268. doi:10.1190/1.1440891

[20] UNEP/IAEA, "Reference Methods for Marine Pollution Studies," Athens, 1986.

[21] T. Tsuda, H. Nakanishi, S. Aoki and J. Takebayashi, "Determination of Butyltin Compounds in Biological and Sediment Samples by Electron-Capture Gas Chromatography," Journal of Chromatography, Vol. 387, 1987, pp. 361-370. doi:10.1016/S0021-9673(01)94538-8

[22] Y. K. Chau, P. T. S. Wong, G. A. Bengert and J. L. Dunn, "Determination of Dialkyllead, Trialkyllead, Tetraalkyllead and Lead (II) Compounds in Sediment and Biological Samples," Analytical Chemistry, Vol. 56, No. 2, 1984, pp. 271-274. doi:10.1021/ac00266a034

[23] M. Meherm, "Assessment of the State of Pollution by Antifouling Paints in Marine Environment of Alexandria Coastal Region," Ph.D. Thesis in Maritime Transport Technology (Environmental Protection), Arab Academy for Science and Technology and Maritime Transport, 2002.

[24] T. O. Said and M. A. Hamed, "Mobility of Polycyclic Aromatic Hydrocarbons in Water of the Egyptian Red Sea Coasts," Bulletin Environmental Contamination and Toxicology, Vol. 77, No. 5, 2006, pp. 126-136. doi:10.1007/s00128-006-1041-8

[25] T. O. Said, "Oil Pollution Inputs into the Suez Gulf, Red Sea," Egyptian Journal of Academic Society Environmental Development (D-Environmental Studies), Vol. 4, 2003, pp. 19-32.

[26] Kh. M. El Moselhy and M. N. Gabal, "Trace Metals in Water, Sediments and Marine Organisms from the Northern Part of the Suez Gulf, Red Sea," Journal of Marine System, Vol. 46, 2004, pp. 39-46. doi:10.1016/j.jmarsys.2003.11.014

[27] Kh. M. El Moselhy, A. A. Diab and M. R. Tolba, L. I. Mohamadein, "Levels of Some Heavy Metals in Coastal Water, Sediment and the Limpet Patella sp. from the Northern Part of the Suez Gulf (Suez Bay)," Egyptian Journal of Aquatic Research, Vol. 3, 1999, pp. 69-84.

[28] Kh. M. El Moselhy and H. Abd El-Azim, "Heavy Metals Content and Grain Size of Sediments from Suez Bay, Red Sea," Egyptian Journal of Aquatic Research, Vol. 31, No. 2, 2005, pp. 224-238.

[29] A. El Sikaily, A. Khaled and A. El Nemr, "Leachable and Total Nine Heavy Metals in Muddy and Sandy Sediment Collected from Suez Gulf. Egypt," Journal of Aqua-tic Research, Vol. 31, 2005, pp. 99-119.

[30] G. Bryan and W. J. Langston, "Bioavailability, Accumulation and Effects of Heavy Metals in Sediments with Special Reference to United Kingdom Estuaries: A Review," Environmental Pollution, Vol. 76, 1992, pp. 89-132. doi:10.1016/0269-7491(92)90099-V

[31] M. C. Barciela-Alonsa, P. Pazos-Capeans, M. E. Regueria-Miguens, A. Bermejo-Barrera and P. Bermejo-Barrera, "Study of Cadmium, Lead and Tin Distribution in Surface Marine Sediment Samples from Ria de Aroua (NW of Spain)," Analytical Chemical Acta, Vol. 524, No. 1-2,
2004, pp. 115-120. doi:10.1016/j.aca.2004.03.087

[32] I. Arambarri, R. Garcia and E. Millan, "Assessment of Tin and Butyltin Species in Estuarine Superficial Sediment from Gipuzkoa, Spain," Chemosphere, Vol. 51, No. 8, 2003, pp. 643-649. doi:10.1016/S0045-6535(03)00154-1

[33] T. A. Delvallas, T. M. Forja and A. Gomez-Parra, "Seasonality of Contamination, Toxicity and Quality Values in Sediments from Littoral Ecosystems in the Gulf of Codiz (SW Spain)," Chemosphere, Vol. 46, No. 7, 2002, pp.1033-1043. doi:10.1016/S0045-6535(01)00176-X

[34] O. F. X. Donard, P. Quevauviller and A. Bruchet, "Tin and Organotin Speciation during Wastewater and Sludge Treatment Processes," Water Research, Vol. 27, No. 6, 1993, pp. 1085-1089. doi:10.1016/0043-1354(93)90073-Q

[35] R. Eisler, "Tin Hazards to Fish, Wildlife, and Invertebrates: A Synoptic Review," Laurel, MD, US Fish and Wildlife Service, Patuxent Wildlife Research Center, (PB-89-139620/XAB), US, 1989.

[36] S. Lin and C. Chen, "Spatial Variations of Heavy Metals in the East China Sea Continental Shelf Surface Sedi-ments," Chemistry and Ecology, Vol. 13, No. 2, 1996, pp. 77-91. doi:10.1080/02757549608035521

[37] P. H. Dowson, J. M. Bubband and J. N. Lester, "Temporal Distribution of Organotins in the Aquatic Environment: Five Years after the 1989 UK Retail Ban on TBT Based Antifouling Paints," Marine Pollution Bulletin, Vol. 26, 1993, pp.487-494. doi:10.1016/0025-326X(93)90465-V

[38] J. P. Meador, C. A. Krone, D. W. Dyar and U. Varanasi, "Toxicity of Sediment Associated Tributyltin in Faunal Invertebrate's Species Comparison and the Role of Organic Carbon," Marine Environmental Research, Vol. 43, No. 3, 1997, pp. 219-241. doi:10.1016/0141-1136(96)00090-6

[39] M. D. Ian, K. Susan and J. C. Melanie, "Tributyltin Inputs to the North Sea from Shipping Activities and Potential Risk of Biological Effects," Journal of Marine Science, Vol. 55, No. 1, 1998, pp. 34-43.

[40] G. E. Batley, "The Distribution and Fate of Tributyltin in the Marine Environment," In: S. J. De Mora, Ed, Tributyltin: A Case Study of an Environmental Contaminant, Cambridge Environmental Chemistry Series, Cambridge University Press, Cambridge, 1996.

[41] ANZECC/ARMCANZ, "Australian and New Zealand Guidelines for Fresh and Marine Water Quality," Australian and New Zealand Environment and Conservation Council/Agriculture and Resource Management Council of Australian and New Zealand Canberra, 2000.

[42] M. A. Shereadah, T.O. Said, G. El Zokm and M. S. Masoud, "Physico-Chemical Characteristics of the Surficial sediments along the Egyptian Red Sea coasts," Egyptian Journal of Aquatic Research, Vol. 34, No. 2, 2008, pp. $83-95$.

[43] C.-C. Lee, C.-Y. Hsieh and C.-J. Tien, "Factors Influencing Organotin Distribution in Different Marine Environmental Compartments and Their Potential Health Risk," 
Chemosphere, Vol. 65, No. 4, 2006, pp. 547-559. doi:10.1016/j.chemosphere.2006.02.037

[44] S. Diez, A. M. Balos and J. M. Bayona, "Organotin Contamination in Sediments from the Western Mediterranean Enclosures following 10 Years of TBT Regulation," Water Research, Vol. 36, 2002, pp. 908-918. doi:10.1016/S0043-1354(01)00305-0

[45] S. Biselli, K. Bester, H. Huhnerfuss and K. Fent, "Concentrations of the Antifouling Compound Irgarol 1051 and of Organotins in Water and Sediments of German North and Baltic Sea Marinas," Marine Pollution Bulletin, Vol. 40, No. 3, 2000, pp. 233-243. doi:10.1016/S0025-326X(99)00177-0

[46] M. M. C. Ko, G. C. Bradley, A. H. Neller and M. J. Broom, "Tributyltin Contamination of Marine Sediments of Hong Kong," Marine Pollution Bulletin, Vol. 31, No. 4, 1995, pp. 249-253. doi:10.1016/0025-326X(95)00138-D

[47] S. D. St-Jean, S. C. Courtenay, E. Pelletier and R. St-Louis, "Butyltin Concentrations in Sediments and Blue Mussels (Mytilus Edulis) of the Southern Gulf of St. Lawrence, Canada," Marine Pollution Bulletin, Vol. 31, No. 4, 1995, pp. 249-253. doi:10.1080/09593332008616807

[48] A. Sudaryanto, S. Takahashi, H. Iwata, S. Tanabe and A. Ismail, "Contamination of Butyltin Compounds in Malaysian Marine Environment," Environmental Pollution, Vol. 130, No. 3, 2004, pp. 347-358. doi:10.1016/i.envpol.2004.01.002

[49] L. Schebek and M. Andreae, "Methyl- and Butyl Compounds in Water and Sediments of the Rhine River," Environmental Science Technology, Vol. 25, No. 5, 1991, pp. 871-878. doi:10.1021/es00017a007

[50] P. H. Dowson, J. M. Bubb, T. P Williams and J. N. Lesterm, "Degradation of Tributyltin in Fresh Water and Estuarine Marine Sediments," Water Science Technology, Vol. 28, 1993, pp.133-137.
[51] F. Cima, P J. Craig and C, Harrington, "Organotin Compounds in the Environment, in Organometallic Compounds in the Environment," John Willey and Sons, Chichester, 2003, pp. 101-149.

[52] WHO (World Health Organization), "Tributyltin Compounds," Environmental Health Criteria 116, Geneva, 1990.

[53] W. E. Pereira, Y. L. Wade, F. D. Hostettler and F. Parchaso, "Accumulation of Butyltins in Sediments and Liquid Tissues of the Asian clam, Potamocorbula Amurensis, Near Mare Island Naval Shipyard, San Francisco Bay," Marine Pollution Bulletin, Vol. 38, No. 11, 1999, pp. 1005-1010. doi:10.1016/S0025-326X(99)00124-1

[54] O. Odoyemi and E. Ajulo, "Stability of Brestan in Tropical Waters," Water Science Technology, Vol. 14, No. 4-5, 1982, pp. 133-142.

[55] D. Muller, "Comprehensive Trace Level Determination of Organotin Compounds in Environmental Samples Using HRGC with FPD," Analytical Chemistry, Vol. 59, No. 4, 1987, pp. 617-623. doi:10.1021/ac00131a017

[56] US EPA (United States Environmental Protection Agency), "Chesapeake Bay Program: Findings and Recommendations. US EPA Report," Region 3, Philadelphia, 1983.

[57] W. J. Lyman "Handbook of Chemical Property Estimation Methods," Washington DC, 1990.

[58] U. Schmidt and F. Huber, "Methylation of Organolead and Lead (II) Compounds to $\left(\mathrm{CH}_{3}\right)_{4} \mathrm{~Pb}$ by Microorganisms," Nature, Vol. 259, 1976, pp. 157-158. doi: $10.1038 / 259157 \mathrm{c} 0$

[59] R. Van Cleuvenbergen, R. Chakraborti and F. Adams, "Occurrence of Triand Dialkyllead Species in Environmental Water," Environmental Science Technology, Vol. 20, 1986, pp. 589-593. doi:10.1021/es00148a007 